\title{
Antropologické zhodnocení kosterních pozůstatků ze slavkovské šibenice u Křenovic
}

\author{
Martin Čuta - Tomáš Mořkovský \\ Ústav antropologie, Př́rodovědecká fakulta Masarykovy univerzity; Kotlářská 267/2, 61137 Brno
}

Do redakce doručeno 9. září 2017; k publikaci přijato 6. listopadu 2017

\section{ANTHROPOLOGICAL ASSESSMENT OF SKELETAL REMAINS FROM THE SLAVKOV GALLOWS}

\begin{abstract}
During a development-led archaeological research of the Slavkov gallows non-anatomically positioned human remains were uncovered in several complex accumulations. The remains were analyzed in a laboratory and fundamental demographic characteristics of the sample were assessed. With regard to the character of the find complete individual skeletons were not identifiable. Minimum number of individuals (MNI, using right femora) was established at 15 . Body height was estimated using the organic correlation method by Sjøvold. The tallest individual measured $173,0 \mathrm{~cm}( \pm 4,52 \mathrm{~cm})$, the shortest individual measured $157,5 \mathrm{~cm}( \pm 4,52 \mathrm{~cm})$. Besides adult individuals also skeletal remains of two adolescents were uncovered (their age at death was estimated at 16-17 years of age). All the adult individuals belonged to the adultus and maturus categories, the oldest one lived to be approximately 50 years old. Skeletal remains of one female were uncovered. Also, the skeletal remains sample yielded some very infrequent anatomical varieties (spina bifida anterior et posterior atlantis, os bregmaticum), evidence of complicated healing process of skeletal trauma as well as evidence of non-healed long bone fractures which originated perimortem. In two cases of long bones evidence of inflammatory disease (likely syphillis) was observed.
\end{abstract}

KEY WORDS gallows; skeletal remains; trauma; anatomical varieties

ABSTRAKT Při záchranném archeologickém výzkumu slavkovské šibenice byly objeveny lidské kosterní pozůstatky, kumulované v několika shlucích v neanatomickém uspořádání. Při laboratorním zpracování byly určeny základní demografické charakteristiky souboru. Vzhledem k charakteru nálezu nebylo možno identifikovat kompletní kostry jedinců. Minimální počet jedinců (s využitím pravých stehenních kostí) byl stanoven na 15. Tělesná výška byla odhadnuta s využitím metody organické korelace dle Sjøvolda. Nejvyšší jedinec měřil $173,0 \mathrm{~cm}( \pm 4,52 \mathrm{~cm})$, nejnižší jedinec měřil $157,5 \mathrm{~cm}( \pm 4,52 \mathrm{~cm})$. Kromě dospělých jedinců byly objeveny i pozůstatky dvou nedospělých jedinců (dožitý věk byl odhadnut na 16-17 let). Všichni dospělí jedinci př́slušeli do věkových kategorií adultus a maturus, nejstarší z nich se dožil kolem 50 let. Mezi kosterními pozůstatky se nacházely ostatky jedné ženy. V souboru byly také nalezeny některé velmi zř́́dka se vyskytující anatomické variety (spina bifida anterior et posterior atlantis, os bregmaticum), doklady komplikovaného hojení traumatu i doklady nezhojených fraktur kostí dlouhého typu vzniklých perimortem. U dvou kostí byly též zaznamenány doklady zánětlivého onemocnění (pravděpodobně syfilis).

KLÍČOVÁ SLOVA šibenice; kosterní pozůstatky; traumata; anatomické variety

ÚVOD

Slavkovská šibenice stávala na výrazném návrší po pravé straně cesty vedoucí ze Slavkova do Křenovic. Jednalo se o významnou krajinnou dominantu - byla umístěna tak, aby byla dobře viditelná z komunikace spojující Slavkov s Křenovice- mi; měla odrazovat potencionální pachatele trestných činů, zvláště mezi nově prí́chozími do Slavkova. Z písemných pramenů (Wojtucki, 2017) i na základě datování zlomků dobové keramiky (Unger, 2017) nalezené při výzkumu šibenice je možno doložit její užívání v 17. a 18. století. Kosterní pozůstatky byly odkrývány postupným odstraňováním vrstev zemi- 
ny. Lidské kosterní pozůstatky (některé dosti fragmentální) byly nalezeny po celé ploše šibenice jednotlivě i ve shlucích a tak nebylo možné jednoznačně identifikovat a rozlišit jednotlivé skelety. Proto bylo možné očekávat, že výsledné demografické charakteristiky budou spíše orientačního charakteru.

\section{MATERIÁL}

K základním analýzám byly využity kosterní pozůstatky vyzvednuté při povrchovém sběru a zjištění půdorysu šibenice v říjnu roku 2015 a zvláště při záchranném archeologickém výzkumu lokality v průběhu dubna roku 2016. Při postupném odkrývání nánosu humusovité zeminy byly objevovány ve vrstvách (od uložení těsně pod povrchem až do hloubky cca $70 \mathrm{~cm}$ ) lidské kosti uložené v několika shlucích v neanatomickém uspořádání. V souboru kostí nebylo možno identifikovat kompletní kostry jedinců.

Z hlediska základní demografické analýzy byl využit celý komplex (často velmi fragmentárních) kosterních pozůstatků, pro odhad pohlaví bylo využito osm pravých pánevních kostí a dvě levé pánevní kosti.

\section{METODY}

Vzhledem $\mathrm{k}$ nemožnosti identifikace jedinců v kumulacích kosterních pozůstatků jsme využili výpočtu MNI (minimálního počtu jedinců). Pro odhad tělesné výšky byla využita metoda organické korelace dle Sjøvolda (1990) - na základě stehenních kostí. Dožitý věk bylo vzhledem k relativně špatné zachovalosti kosterních pozůstatků možno odhadovat pouze dle Lovejoyovy (1985) metody hodnocení zubní abraze, pro doplnění bylo také využito orientační metody hodnocení obliterace lebečních švů (Meindl - Lovejoy 1985). Věk nedospělých jedinců byl odhadován dle Schaefer, Black, Scheuer (2009) - na základě uzavírání růstových chrupavek. Pohlaví bylo předběžně odhadnuto aspektivní metodou hodnocení morfoskopických znaků na pánevních kostech dle Acsádi-Nemeskéri (1970), vlastní analýza byla provedena morfometrickou metodou DSP (Murail et al. 2005). Zaznamenali jsme výskyt anatomických variet, které byly zhodnoceny vizuálně. Některé z kostí vykazovaly stopy traumatických zásahů a patologické změny. Ty byly v prvotní fázi výzkumu též zhodnoceny vizuálně, podrobnější zhodnocení bude popsáno v samostatné publikaci.

\section{VÝSLEDKY}

\section{Minimální počet jedinců}

Minimální počet jedinců (MNI) byl stanoven na 15. Po důkladném posouzení kompletnosti skeletního souboru byl minimální počet jedinců vypočten podle počtu pravých stehenních kostí (kompletních či jejich určitelných fragmentů).

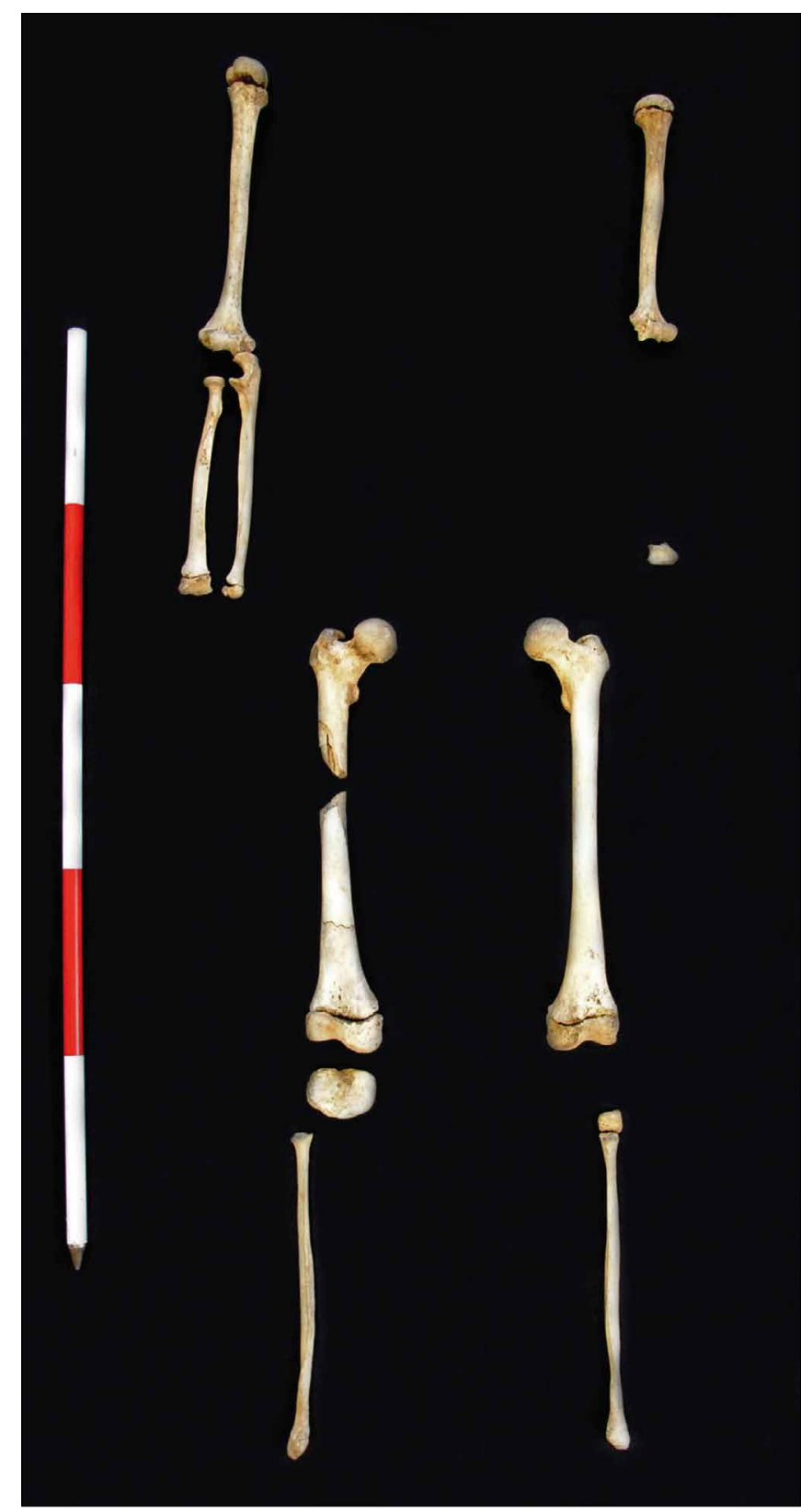

Obr. 1. Dochované části skeletu jednoho z juvenilních jedinců.

\section{Tělesná výška}

Tělesná výška byla odhadována z pravých stehenních kostí pomocí metody dle Sjøvolda (1990). Celkem bylo možno využít 7 femurů, zachovalost ostatních kostí neumožňovala změřit jejich délku. Nejvyšší jedinec měřil $173,0 \mathrm{~cm}( \pm 4,52$ $\mathrm{cm})$, nejnižší jedinec měřil $157,5 \mathrm{~cm}( \pm 4,52 \mathrm{~cm})$.

\section{Dožitý věk}

U dospělých jedinců byl věk hodnocen vzhledem $\mathrm{k}$ fragmentárnosti kosterních nálezů metodou hodnocení zubní abraze. Všichni dospělí jedinci příslušeli do kategorií adultus a maturus, nejstarší jedinec se dožil cca 50 let. 


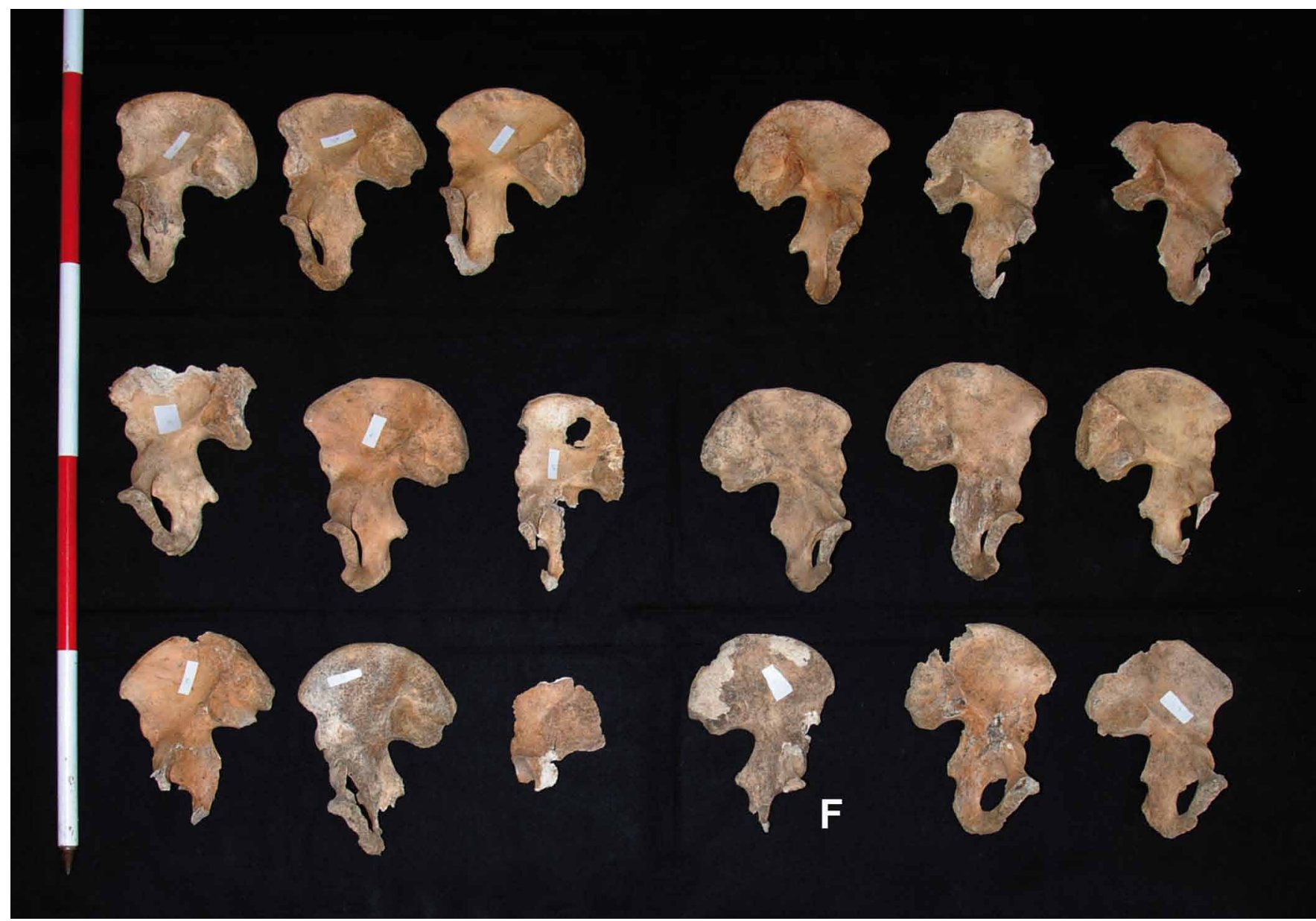

Obr. 2. Pánevní kosti objevené při odkrývání šibenice. Kost označená „F“ náležela ženě.

V souboru byly objeveny i kosterní pozůstatky juvenilních jedinců. Mezi nimi se nám podařilo s největší pravděpodobností identifikovat pozůstatky dvou jedinců (Obr. 1). Dle Schaefer, Black, Scheuer (2009) byl na základě posloupnosti uzavírání růstových chrupavek věk obou jedinců stanoven na $16-17$ let.

\section{Pohlaví}

Odhad pohlaví byl proveden pomocí metody DSP (Murail et al. 2005), které předcházelo předběžné aspektivní hodnocení (Acsádi-Nemeskéri 1970). Předběžné zhodnocení pravých pánevních kostí neodhalilo žádnou pánevní kost s femininními znaky. U levých pánevních kostí jsme pomocí morfoskopické metody zhodnotili, že dvě pánevní kosti vykazují zřetelné femininní charakteristiky. Dle všech hodnotitelných pravých pánevních kostí byli dle výsledků metody DSP nalezení jedinci muži, s tím, že u dvou jedinců nebylo možné rozhodnout o pohlaví. Metodou DSP jsme zhodnotili i dvě femininní (dle vizuálního předběžného zjištění) levé pánevní kosti a $\mathrm{z}$ výsledků tohoto hodnocení vyplývá, že jedna $\mathrm{z}$ levých pánevních kostí náležela ženě (Obr. 2); u druhé pánevní kosti nebylo možno rozhodnout o pohlaví.

\section{Anatomické variety}

Na kostech postkraniálního skeletu byly zaznamenány následující variety:

Spina bifida atlantis anterior et posterior (Obr. 3). U této variety je udávána velmi nízká četnost výskytu - 0,1\%, jedná se tedy o vzácný znak.

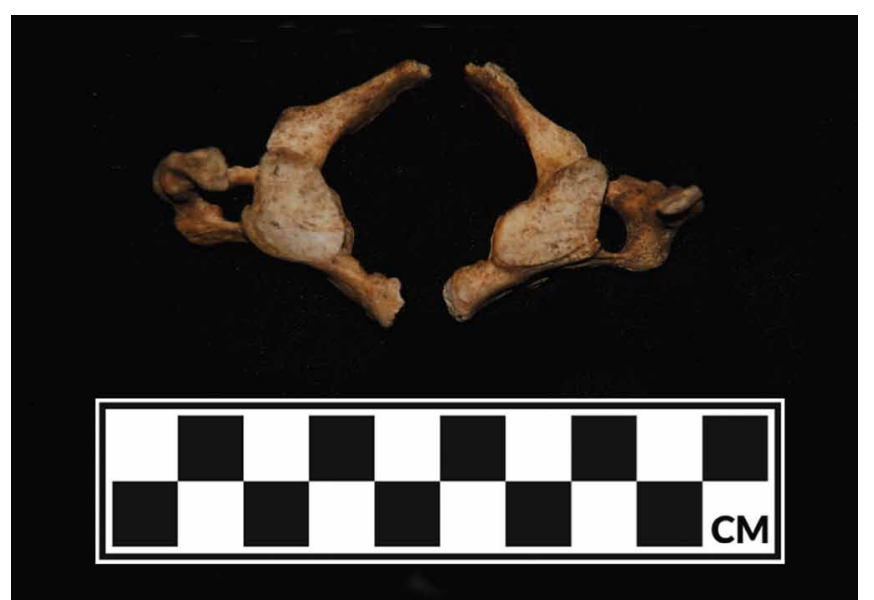

Obr. 3. Spina bifida atlantis anterior et posterior. 


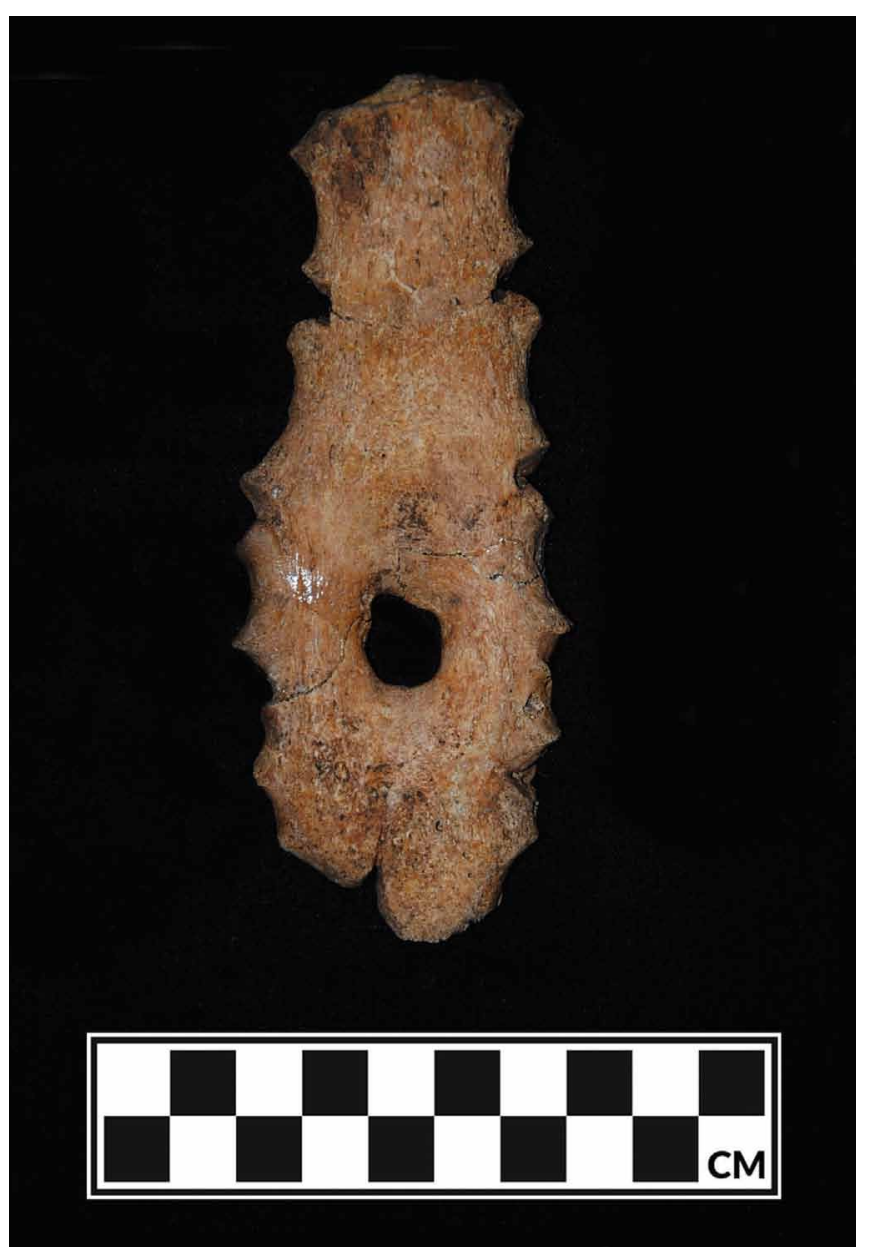

Obr. 4. Jeden ze zaznamenaných př́padů fenestratio corporis sterni.

Dále byly zaznamenány dva prrípady fenestratio corporis sterni (Obr. 4) a dva př́pady foramen supratrochleare (Obr. 5). Jedná se o méně vzácné variety.

Na kostech lebky byla zaznamenána os bregmaticum (Obr. 6). Patři mezi vsunuté kůstky, které bývají přítomny v lebečních švech či v místech jejich kř́žzní. Výskyt této variety je poměrně vzácný - udává se četnost výskytu pod $1 \%$.

Do této sekce je zařazen jeden $\mathrm{z}$ epigenetických znaků, jehož rozvoj/robusticita je považován za výrazně sexuálně dimorfní (nejde tedy o varietu) - jedná se o rozvoj oblasti trigonum mandibulae (Obr. 7). U mandibul čtyř jedinců jsme zaznamenali výrazně robustní morfologii této oblasti.

\section{Stopy traumat na kostech}

Na tělech kostí dlouhého typu byly nalezeny fraktury s největši pravděpodobností vzniklé perimortem - v době velmi blízké okamžiku smrti. Jednalo se celkem o 14 zlomenin na kostech volné horní a dolní končetiny. V 5 př́ípadech (2 př́pady na kosti stehenní, dále na kosti holenní, kosti lýtkové a na kosti vřetenní) jsme pozorovali tzv. motýlkový typ zlomeniny s vylomeným fragmentem trojúhelníkového tvaru, které jsou typické pro zlomeniny způsobené tlakem působí-

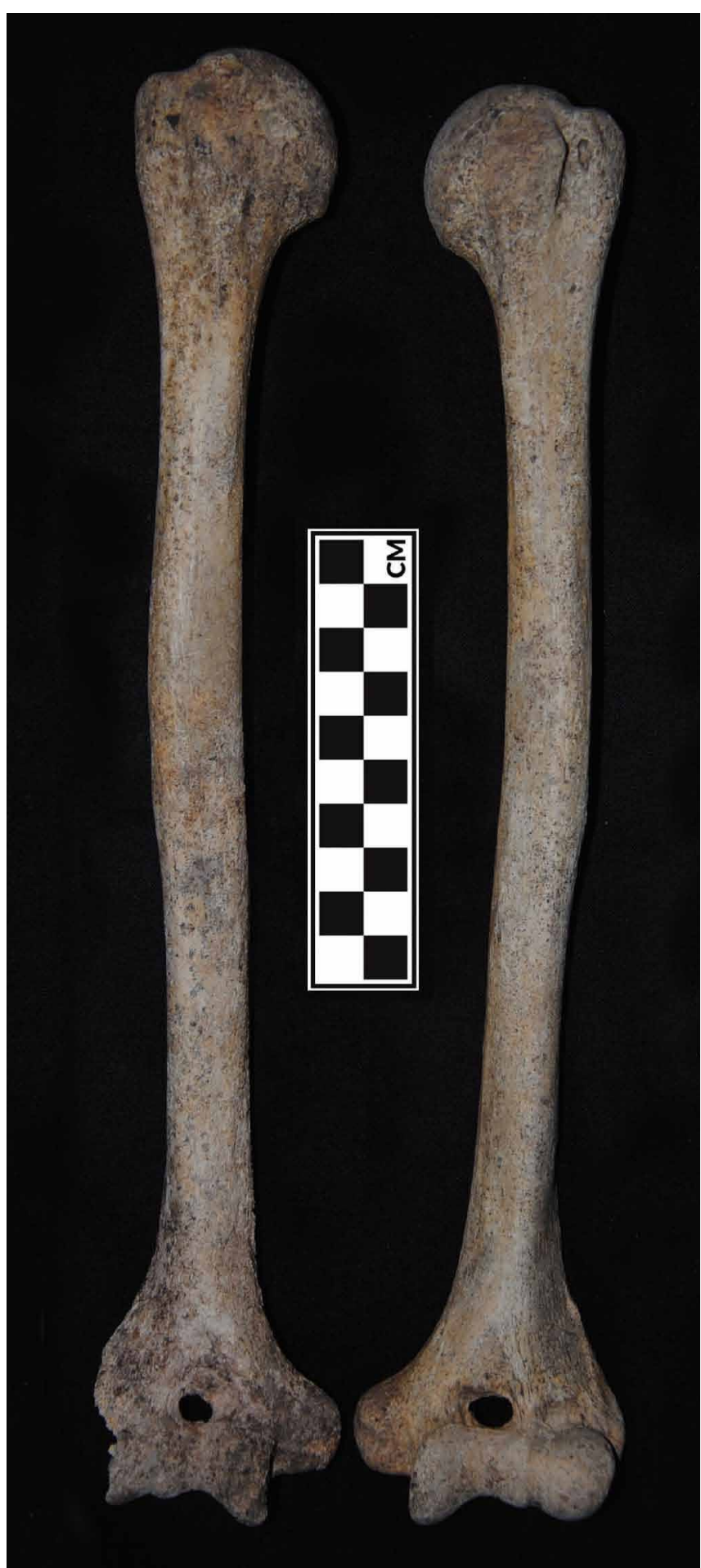

Obr. 5. Dva zaznamenané př́pady foramen supratrochleare náležely pravděpodobně jednomu jedinci.

cím kolmo na podélnou osu kosti (Obr. 8); zvláště tento typ zlomeniny by odpovídal vzniku zlomeniny při lámání kolem. V jednom případu pažní kosti byl pozorován případ spirálové zlomeniny. Na fragmentu distálního konce stehenní kosti (Obr. 9) byla nalezena perimortem vzniklá stopa po ostrém předmětu. Na lebce č. 6 byla ve frontální/temporální krajině nalezena perimortem stopa po ostrém předmětu. 

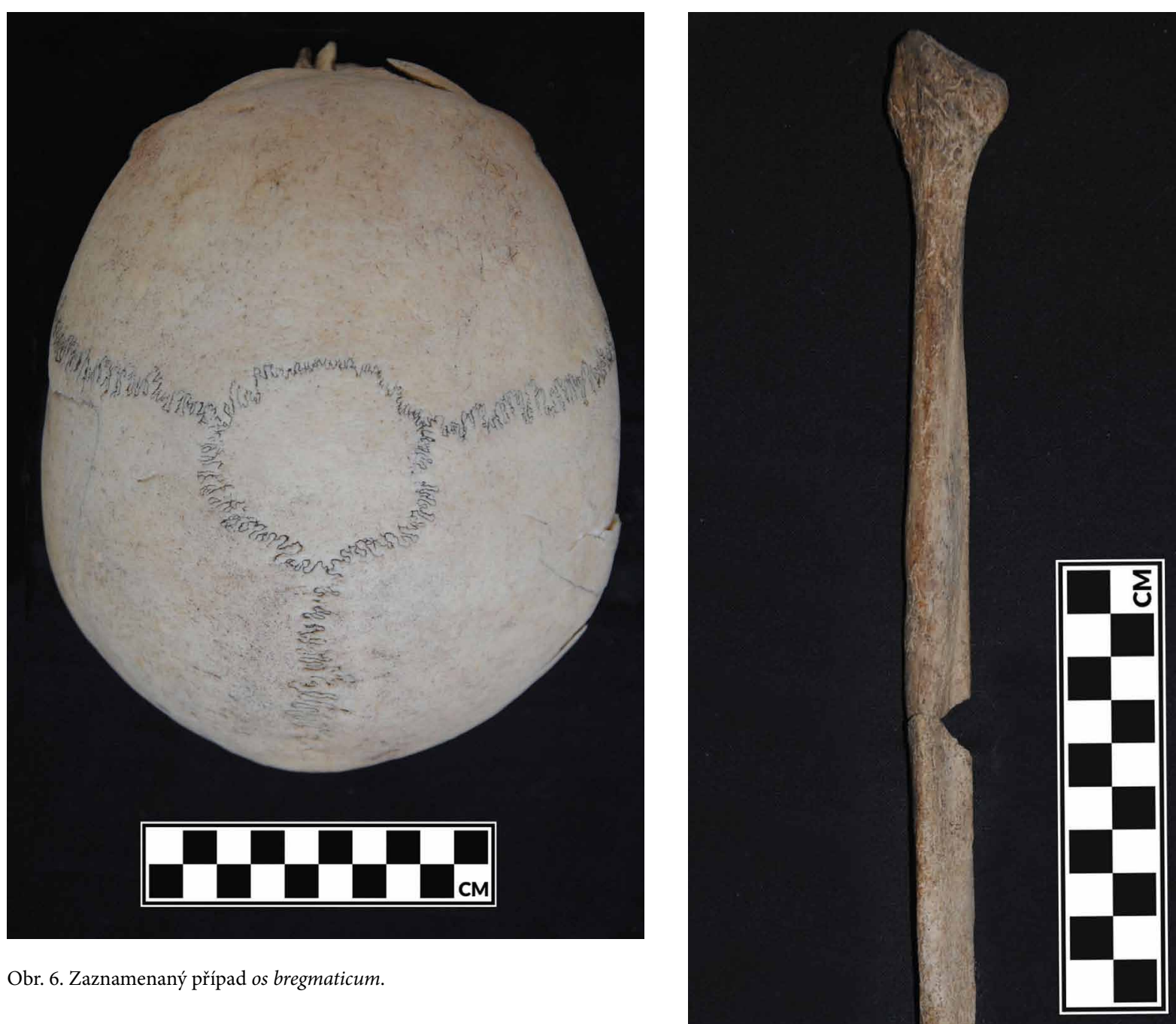

Obr. 6. Zaznamenaný př́pad os bregmaticum.

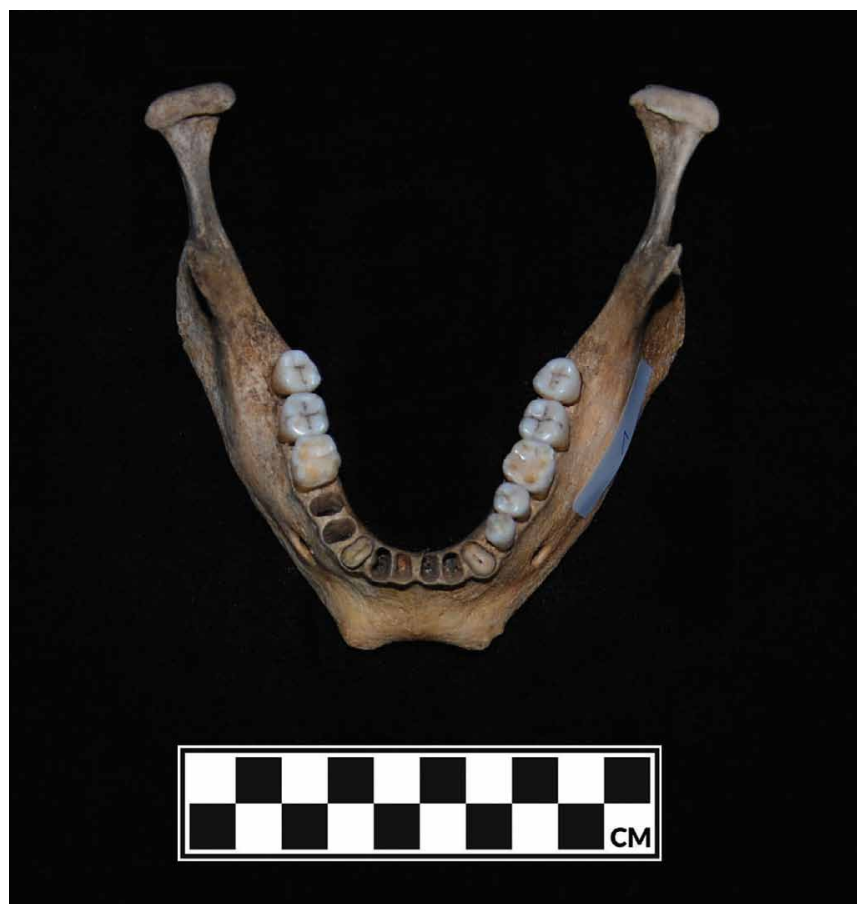

Obr. 7. Jeden z př́ípadů dolní čelisti s robustním trigonum mandibulae.

Obr. 8 Př́iklad motýlkovité zlomeniny na lýtkové kosti. 

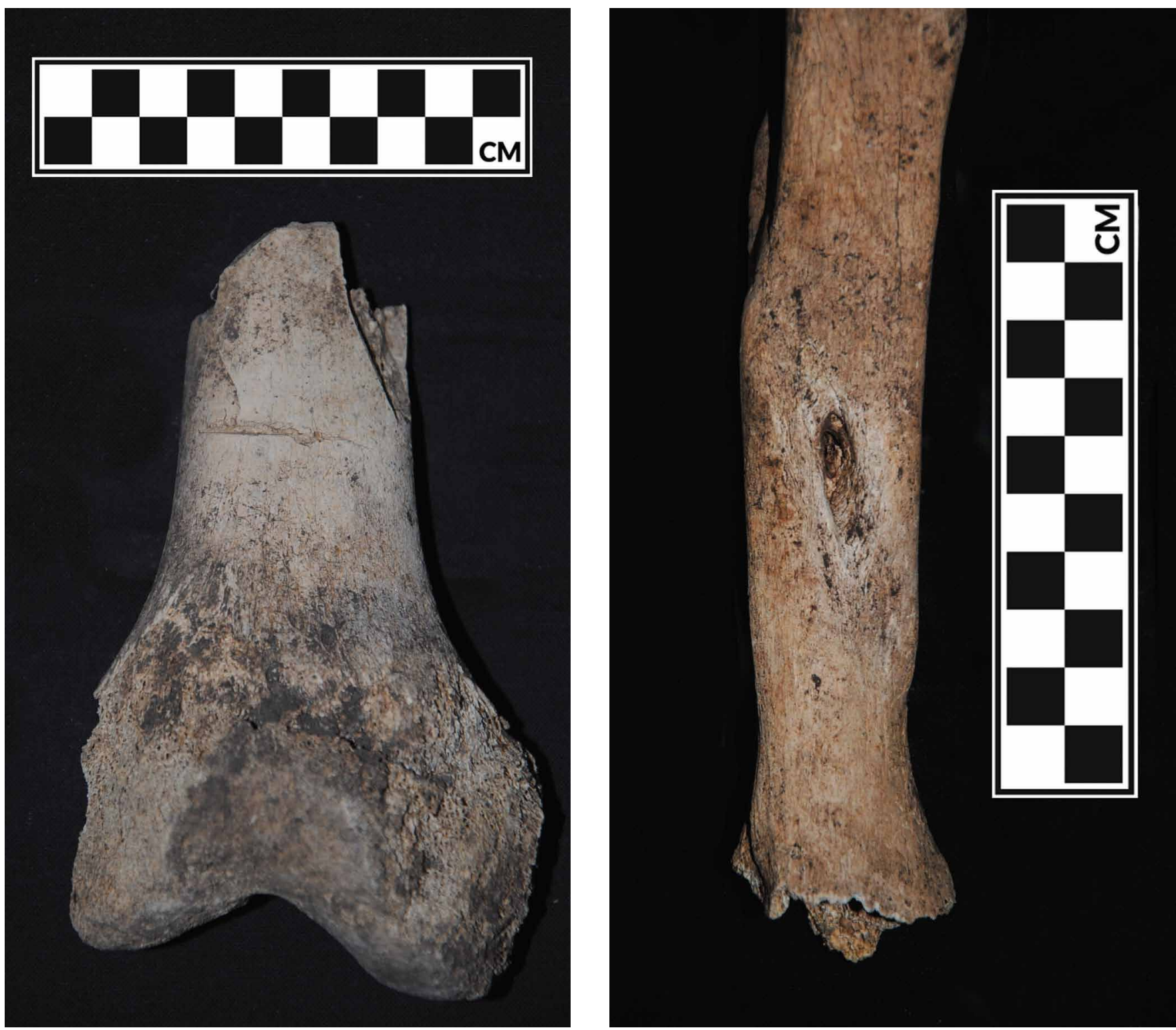

Obr. 9. Stopa po ostrém předmětu na fragmentu distálního konce pravé stehenní kosti

\section{Projevy patologických procesů na skeletu}

Pravá holenní kost (tibia č. 2) vykazovala známky komplikací při hojení zlomeniny - jednalo se o šikmou zlomeninu ve středu těla kosti, linie lomu probíhala šikmo na podélnou osu kosti. Srůst je nerovný, kost byla postižena zánětlivým procesem, zřetelná je píštěl evakuující sekret ze zánětlivého ložiska (Obr. 10).

Pravá holenní kost (tibia č. 1) byla výrazně ztluštělá v distální části těla (Obr. 11). Ztluštění bylo vyhodnoceno jako projev chronické osteomyelitidy, podezření na syfilis bude potvrzeno či vyvráceno další analýzou. Projev chronické osteomyelitidy (ložisko novotvořené tkáně v důsledku zánětlivých změn) byl pozorován také na fragmentu distální části pravé pažní kosti. I v tomto prrípadě bude podezření na syfilis potvrzeno či vyvráceno další analýzou.

\section{DISKUSE}

\section{Depozice tělesných ostatků popravených/tafonomie}

Kosterní pozůstatky byly odkrývány postupně v promíšených vrstvách humusovité zeminy v několika shlucích, bez zjevného anatomického uspořádání. Je pravděpodobné, že kosti se do těchto shluků dostaly kumulací pozůstatků různých částí těl více jedinců při tzv. úklidu popraviště - zřejmě se po přirozené dekompozici/disartikulaci nacházely volně na plošině šibenice a odtud byly shrnuty dolů do vlastního prostoru zděné stavby (před následující popravou). Po zpracování v laboratoři byly na řadě kostí pozorovatelné zřetelné, čisté lomové linie. Vznik čistých lomových linií (nevykazovaly známky hojení, avšak nic nenasvědčovalo ani tomu, že by se jednalo o lom na dlouho pohřbených, křehkých kostech) nelze při- 
čítat úklidu šibenice, ale jedná se pravděpodobně o doklady zostřujících trestů (lámání kolem).

\section{Minimální počet jedinců}

Při stanovení minimálního počtu jedinců je možné užít několika variací obecného principu - v našem prípadě jsme vzhledem $\mathrm{k}$ povaze uložení kosterního materiálu, které připomínalo uložení lidských pozůstatků v masovém hrobu, využili jednoduchého součtu kostí (či jejich fragmentů) jedné strany (v případě fragmentů muselo být jasné, že nemohly náležet jednomu jedinci). V našem souboru byla nejvíce zastoupena pravá stehenní kost, tato kost tedy byla využita pro výpočet MNI.

\section{Odhad věku}

Pro odhad dožitého věku dospělých jedinců byla využita Lovejoyova metoda (1985), která je založena na hodnocení stupně zubní abraze. Pro alespoň relativní zpřesnění byla využita také metoda Meindla a Lovejoye (1985), založená na stupni obliterace lebečních švů.

Metody založené na hodnocení stupně zubní abraze jsou v antropologické praxi považovány za nejméně přesné, vzhledem k jejich výraznému ovlivnění výživou, velikostí čelistí a dalšími faktory, které způsobují velkou variabilitu míry opotřebení a vzorců její změny (Hojo 1954). Někteří autoři však tyto metody považují za vhodné pro odhad věku, zvláště v archeologických studiích populací, které nejsou zasaženy zjemněním stravy a snížením abrazivních účinků (Molnar et al. 1983; Kim et al. 2000; Miles 2001). Metody založené na hodnocení doby srůstání a uzávěru lebečních švů jsou ovlivněny velkou variabilitou doby začátku i ukončení srůstání. Doba srůstání lebečních švů je sexuálně dimorfním znakem (Masset 1971; Hajniš - Novák 1984), proto je odhad věku na tomto základě možno považovat spíše za orientační. Zvláště ve vyšších věkových kategoriích může chyba odhadu dosahovat i 10 a více let (Masset 1971).

Alternativní metody ze skupiny makroskopických-osteologických metod (sledování změn na sternálním konci klíční kosti či na facies symphysialis ossis pubis) byly vzhledem $\mathrm{k}$ fragmentární povaze kosterního materiálu neproveditelné.

\section{Odhad pohlaví}

Odhad pohlaví byl proveden s využitím SW DSP (Murail et al. 2005). Tato metoda je vhodná pro zhodnocení kosterních pozůstatků ze slavkovské šibenice. Za prvé, metoda DSP má vysokou senzitivitu (99,63\% na původním souboru), na současné populaci Francouzů až $100 \%$ (Chapman et al. 2014; Mesteková et al. 2015). Je vhodná i pro novověké populace (je uváděno, že je využitelná pro populace od počátku 18. století do současnosti. Toto časové rozpětí odpovídá době užívání šibenice - ze záznamů apelačního soudu v Praze bylo zjištěno, že ještě v roce 1731 proběhly dvě popravy. Výstup SW DSP (tedy jedna ženská pánevní kost) byl potvrzen i nálezem v písemných pramenech - v roce 1723 byla provedena poprava Kateřiny Hawlatkové, která byla pohřbena na šibenici.

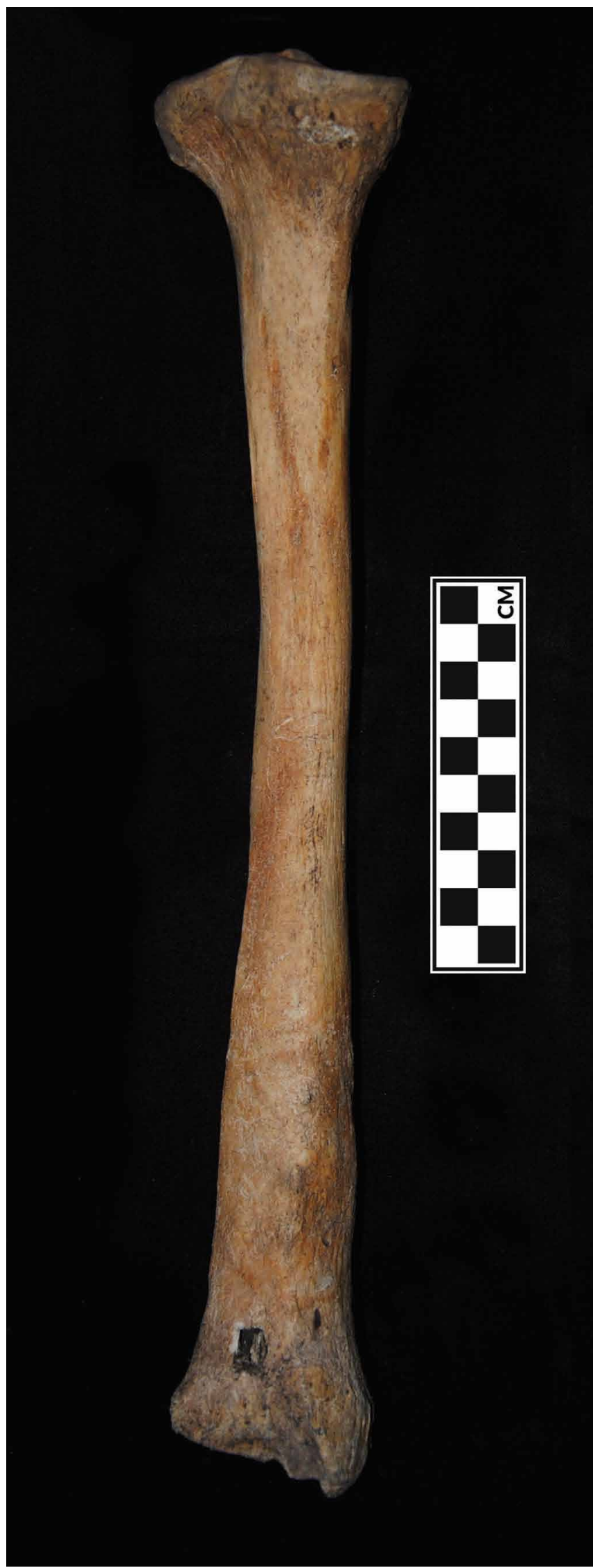

Obr. 11. Projev chronické osteomyelitidy na pravé holenní kosti. 


\section{Anatomické variety}

Přes nízký počet jedinců bylo ve zkoumaném souboru pozorováno několik anatomických variet. Byly zde zastoupeny variety, jejichž výskyt je poměrně častý (foramen supratrochleare humeri, fenestratio corporis sterni) i vzácnější variety - os bregmaticum a spina bifida atlantis anterior et posterior.

Foramen supratrochleare humeri je otvor, který může být přitomen $\mathrm{v}$ přepážce mezi fossa olecrani a fossa coronoidea $\mathrm{v}$ distální části kosti pažní (Ward 2016). Mechanismy jeho vzniku nejsou dosud jednoznačně vysvětleny a mezi badateli existuje řada hypotéz, jež ve své studii přehledně shrnul Erdogmus s kolektivem (2014). U nedospělých jedinců bývá zaznamenán jen velmi zř́dka a jeho formování spadá ve většině případů do období rané dospělosti (Mays 2008). Většina studií zaznamenala vyšší výskyt této variety u žen (Diwan et al. 2013; Benfer-McKern 1966; Ndou et al. 2013; Mays 2008). Výskyt otvoru byl u většiny zkoumaných populací častější na levých pažních kostech (Erdogmus et al. 2014; Patel et al. 2013).

Je pravděpodobné, že dva prípady foramen supratrochleare humeri zaznamenané ve zkoumaném vzorku jsou přiřaditelné jednomu jedinci. Frekvence výskytu této variety se pohybuje v širokém rozmezí od téměř $0 \%$ do $58 \%$ v závislosti na populaci (Papaloucas et al. 2011). Nejvyšší výskyty byly zaznamenány u afrických a indických populací, u domorodých austrálcủ či amerických indiánů (Li et al. 2015). Moderní evropské populace, $\mathrm{k}$ nimž můžeme přriřadit i námi zkoumaný soubor, vykazují nižší frekvence výskytu tohoto znaku pohybující se v rozmezí 1-10\% (Erdogmus et al. 2014). Z klinického hlediska může být prítomnost foramen supratrochleare humeri významná při volbě vhodné strategie léčby zlomenin v distální ćásti kosti pažní (Paraskevas et al. 2010).

Další anatomickou varietou, která byla ve zkoumaném souboru zaznamenána ve dvou př́ípadech, byl otvor v těle hrudní kosti (fenestratio corporis sterni). Jedná se o kruhový či oválný defekt, který se nejčastěji nachází v dolní třetině těla hrudní kosti. Vzniká $\mathrm{v}$ průběhu vývoje nedokonalým splynutím osifikačních center na těle hrudní kosti (Bermio-Jos Hemalatha 2014). Studie velkých populačních vzorků $\mathrm{z}$ celého světa udávají četnost výskytu 4-8\% (Yekeler et al. 2006; Ishii et al. 2011; Moore et al. 1988; McCormick 1981). Ve forenzních př́ípadech může být při neznalosti otvor zaměněn za bodné či stř̌lné poranění hrudní kosti. Naopak při vhodném použití zdravotní dokumentace může sloužit $\mathrm{k}$ zúžžení okruhu hledaných jedinců. Z klinického hlediska je třeba vyvarovat se záměny za osteolytické léze či metastázy při RTG vyšetření. Přítomnost otvoru může zvyšovat riziko poškození srdce či plic při odběru kostní dřeně ze sterna či při akupunktuře $(\mathrm{Pa}-$ raskevas et al. 2015).

$\mathrm{V}$ souboru byla prítomna i poměrně vzácná varieta spina bifida atlantis anterior et posterior. Jedná se o jev, kdy nedojde ke spojení pravého a levého základu předního oblouku atlasu, přičemž se nespojí ani pravý a levý základ zadního oblouku atlasu.

$\mathrm{Na}$ jedné ze zkoumaných lebek byla prítomna os bregmaticum. Jedná se vmezeřenou kost nacházející se v oblasti kř́i- žení sutura coronalis a sutura sagittalis v místě, kde se v průběhu ontogeneze nachází velký lupínek - fonticulus major (Tunali 2016). Patří mezi vsunuté kůstky, které bývají př́itomny v lebečních švech či v místech jejich křížení a řadí se mezi nemetrické znaky či variety (Hauser-De Stefano 1989). Přítomnost vsunutých kůstek je obecně poměrně běžná a kolísá u různých populací mezi 40-80 \% (Brothwell 1963). Nejčastěji se vyskytují v lambdovém švu - sutura lambdoidea (Murlimanju et al. 2011). Výskyt os bregmaticum je však poměrně vzácný. $\mathrm{V}$ mnoha zkoumaných populačních vzorcích se nevyskytuje vůbec (Radović - Miladinović-Radmilović 2013, 1639), v jiných kolísá její prŕtomnost od 0,2 do 2,5\% (Nikolova et al. 2016; Hauser - De Stefano 1989; Berry - Berry 1967). V souboru 657 jedinců z českého prostředí byla její prítomnost zaznamenána $\mathrm{v} 0,2 \%$ př́ípadů (Barberini et al. 2008, 686). V lokalitě na Pískách byla z 245 zkoumaných př́ípadů zaznamenána pouze jednou (Hrnčíŕová 2007). Př́ipad nálezu os bregmaticum z českého prostředí, který byl původně mylně interpretován jako trepanace popsal Becker (2003). Př́tomnost os bregmaticum v námi zkoumaném souboru jedinců tak představuje jeden ze vzácných výskytů této variety u populace $\mathrm{z}$ období novověku.

\section{Stopy traumat na kostech}

Fraktury na kostech končetin (kostech dlouhého typu) byly zhodnoceny (makroskopicky podle povrchu lomových ploch fragmentů) tak, že vznikly v době (nebo v době blízké) okamžiku smrti př́slušných jedinců. Na fragmentech nebyly žádné pozorovatelné stopy reparačního procesu. Dle vizuálního zhodnocení kostí bylo také patrné, že lomové linie s největší pravděpodobností nevznikly vlivem tafonomických procesů - povrch kostí je hladký a lomová linie ostrá a nejsou patrné „zubatée a jakoby „otrhané“ okraje zlomů typické pro kosti zlomené postmortem.

\section{Projevy patologických zánětlivých projevů na kostech}

Stopy zánětu byly ve zkoumaném souboru objeveny na dvou kostech - na pravé holenní kosti a na fragmentu distální části pravé pažní kosti. Na pravé holenní kosti bylo v její distální části lokalizováno zřetelné ztluštění. Při laboratorním zpracování kostí byla na základě vizuálního zhodnocení stanovena diagnóza - chronická osteomyelitida jakožto projev suspektní syfilis. Lokalizace kosterních projevů je nejčastější právě na holenních kostech (Horáčková - Strouhal - Vargová, 2004), proto se zdá pravděpodobné, že dotyčný jedinec trpěl třetím (tzv. orgánovým) stádiem tohoto chronického infekčního onemocnění. Na distální části pravého humeru byly př́tomny pláty novotvořené kostní tkáně, taktéž charakteristické pro chronickou osteomyelitidu. Lokalizace syfilitických ložisek na humeru je také relativně častá (Horáčková - Strouhal - Vargová 2004). Na našem území bylo zdokumentováno relativně výrazně nižší množství paleopatologických nálezů syfilitických změn na kostech, než jaké by odpovídalo literárním údajům o hromadném výskytu tohoto onemocnění 
(Horáčková - Strouhal - Vargová 2004). Přesto existují práce $\mathrm{z}$ našeho prostředí popisující $\mathrm{v}$ ucelenějším kontextu stopy po syfilitické nákaze na kosterních pozůstatcích (Vlček 1996, Vlček 1989), mimo jiné $\mathrm{z}$ období provozu šibenice - 17. a 18. století (Vargová - Horáčková 1999).

\section{ZÁVĚR}

Antropologické zpracování kosterních pozůstatků přineslo zajímavé poznatky doplňující představu o hrdelním právu a hrdelních trestech v novověkých městech Čech a Moravy. Popravování byli i nedospělí jedinci, výjimečné nebyly popravy žen. Byly objeveny doklady pravděpodobného zostřujícího trestu v podobě lámání kolem. Na šibenici též byly nalezeny stopy po syfilitické nákaze na kosterních pozůstatcích a taktéž zajímavá kumulace (vzhledem k nízkému počtu deponovaných jedinců) relativně vzácných variet kosterního systému.

\section{LITERATURA}

Acsádi, G. - Nemeskéri, J. (1970): History of human life span and mortality. Budapest: Akadémiai Kiadó.

Barberini, F. - Bruner, E. - Cartolari, R. - Franchitto, G. - Heyn, R. - Ricci, F. - Manzi, G. (2008): An unusually-wide human bregmatic Wormian bone: anatomy, tomographic description and possible significance. Surgical and Radiologic Anatomy, 30(8), 683-687.

Becker, M. J. (2003): A bregmatic ossicle resembling a trepanation from an eleventh-century skeleton excavated from a cemetery area now within the Prague castle, Czech Republic. In: Trepanation. History, Discovery, Theory. (Arnott, R.-Finger, S.-Smith, C.U.M., edd.), 155-162, Lisse, The Netherlands.

Benfer, R. A. - McKern, T. W. (1966): The correlation of bone robusticity with the perforation of the coronoid-olecranon septum in the humerus of man. American Journal of Physical Anthropology, 24(2), 247-252.

Bermio, V.S. - Jos Hemalatha, G.A. (2014): Congenital foramen in the body of sternum. International Journal of Anatomy and Research, 2(3), 545-548.

Berry, A. C. - Berry, R. J. (1967): Epigenetic variation in the human cranium. Journal of Anatomy, 101, 361-379.

Brothwell, D. (1963): Digging Up Bones. London.

Diwan, R. K. - Rani, A. - Rani, A. - Chopra, J. - Srivastava, A. K. - Sharma, P. K. - Verma, R. K. - Pankaj, A. K. (2013): Incidence of Supratrochlear foramen of Humerus in North Indian Population. Biomedical Research, 24(1), 142-145

Erdogmus, S. - Guler, M. - Eroglu, S. - Duran, N. (2014): The Importance of the Supratrochlear Foramen of the Humerus in Humans: An Anatomical Study. Medical Science Monitor, 20, 2643-2560.

Hajniš, K. - Novák, J. T. (1984): Srůst švů lebeční klenby. Praha: Avicenum

Hauser, G.- De Stefano, G. F. (1989): Epigenetic variants of the human skull. Stuttgart.

Hojo, M. (1954): On the pattern of the dental abrasion. Okajimas Folia Anatomica Japonica, 26(1-2), 11-30.

Horáčková, L. - Strouhal, E. - Vargová, L. (2004): Základy paleopaotologie. (Panoráma biologické a sociokulturní antropologie). Akademické nakladatelství CERM, Brno.

Chapman, T. - Lefevre, P. - Semal, P. - Moiseev, F. - Sholukha, V. - Louryan, S. - Rooze, M. - Van Sint Jan, S. (2014): Sex determination using the Probabilistic Sex Diagnosis (DSP: Diagnose Sexuelle Probabiliste) tool in a virtual environment. Forensic Science International, 234, 189.e1-189.e8.

Ishii, S. - Shishido, F. - Miyajima, M. - Sakuma, K. - Shigihara, T. - Kikuchi, K. - Nakajima, M. (2011): Causes of photopenic defects in the lower sternum on bone scintigraphy and correlation with multidetector CT. Clin Nucl Med, 36(5), 355-358.
Kim, Y. - Kho, H. - Lee, K. (2000): Age estimation by occlusal tooth wear. Journal of Forensic Sciences, 45(2), 303-309.

Li, J. - Mao, Q. - Li, W. - Li, X. (2015): An anatomical study of the supratrochlear foramen of the Jining population. Turkish Journal of Medical Sciences, 45, 1369-1373.

Lovejoy, C. O. (1985): Dental wear in the Libben population: Its functional pattern and role in the determination of adult skeletal age at death. American Journal of Physical Anthropology, 68(1), 47-56.

Masset, C. (1971): Erreurs systématiquies dans la détermination de l'age par les sutures craniennes. Bulletins et Mémoires de la Société d'anthropologie de Paris, 7(1), 85-105.

Mays, S. (2008): Septal aperture of the humerus in a mediaeval human skeletal population. American Journal of Physical Anthropology, 136, 432-440.

McCormick, W. F. (1981): Sternal foramena in man. Am J Forensic Med Pathol, 2(3), 249-252.

Meindl, R. S. - Lovejoy, C. O. (1985): Ectocranial suture closure: A revised method for the determination of skeletal age at death based on the lateral-anterior sutures. Am. J. Phys. Anthropol., 68(1), 57-66.

Mesteková, S. - Brůžek, J. - Velemínská, J. - Chaumoitre, K. (2015): A Test of the DSP Sexing Method on CT Images from a Modern French Sample. Journal of Forensic Sciences, 60(15), 1295-1299.

Miles, A. E. W. (2001): The Miles method of assessing age from tooth wear revisited. Journal of Archaeological Science, 28(9), 973-982.

Molnar, S. - McKee, J. K. - Molnar, I. M. - Przybeck, T. R. (1983): Tooth wear rates among contemporary Australian Aborigines. Journal of Dental Research, 62(5), 562-565.

Moore, M. K. - Stewart, J. H. - McCormick, W. F. (1988): Anomalies of the human chest plate area. Radiographic findings in a large autopsy population. Am J Forensic Med Pathol, 9(4), 348-354.

Murail, P. et al. (2005): DSP: A tool for probabilistic sex diagnosis using worldwide variability in hip-bone measurements. Bulletins et mémoires de la Société d'Anthropologie de Paris, 17(3-4), 167-176.

Murlimanju, B. V. - Prabhu, L. V. - Ashraf, C. M. - Kumar, C. G. - Rai, R. - Maheshwari, C. (2011): Morphological and topographical study of Wormian bones in cadaver dry skulls. Journal of Morphological Sciences, 28(3), 176-179.

Ndou, R. - Smith, P. - Gemell, R. - Mohatla, O. (2013): The Supratrochlear Foramen of the Humerus in a South African Dry Bone Sample. Clinical Anatomy, 26, 870-874.

Nikolova, S. - Toneva, D. - Georgiev, I. - Yordanov, Y. - Lazarov, N. (2016): Two cases of large bregmatic bone along with a persistent metopic suture from necropoles on the northern Black Sea coast of Bulgaria. Anthropological Science, 124(2), 145-153.

Papaloucas, C. - Papaloucas, M. - Stergioulas, A. (2011): Rare Cases of Humerus Septal Apertures in Greeks. Trends in Medical Research, 6(3), $178-83$.

Paraskevas, G.K. - Papaziogas, B. - Tzaveas, A. - Giaglis, G. - Kitsoulis, P. NATSIS, K., 2010: The supratrochlear foramen of the humerus and its relation to the medullary canal: A potential surgical application. Med Sci Monit, 16, 119-123.

Paraskevas, G. - Tzika, M. - Anastasopoulos, N. - Kitsoulis, P. - Sofidis, G. Natsis, K. (2015): Sternal foramina: incidence in Greek population, anatomy and clinical considerations. Surg Radiol Anat, 37, 845-851.

Patel, S. V. - Sutaria, L. K. - Nayak, T. V. - Kanjiya, D. P. - Patel, B. M. Aterkar, S. H. (2013): Morphometric study of supratrochlear foramen of humerus. International Journal of Biomedical And Advance Research, $4(2), 89-92$.

Radović, P. - Miladinović-Radmilović, N. (2013): A large supernumerary bone at the bregma and metopism co-occurring in the skull of ancient roman in Serbia. Archives of Biological Sciences, 65(4), 1637-1643.

Schaefer, M. - Black, S. - Scheuer, L. (2009): Juvenile osteology. A laboratory and field manual. Elsevier, London.

Sjøvold, T. (1990): Estimation of stature from long bones utilizing the line of organic correlation. Hum. Evol., 5(5), 431.

Tunali, S. (2016): Skull. In: Bergman's Comprehensive Encyclopedia of Human Anatomic Variation (Tubbs, R. S.- Shoja, M. M.- Loukas, M., edd.) $1-21$. Hoboken, New Jersey, USA.

Unger, J. (2017): Archeologický výzkum slavkovské šibenice u Křenovic. Anthropologia Integra, 8(2), 7-13. 
Vargová, L. - Horáčková, L. (1999): The study of inflammatory diseases in osseous material from Early modern - era Moravian localities. Scripta medica, 72 (5-6), 185-192.

Vlček, E. (1989): Paläopathologische Nachweise der Syphilis in Böhmen im 17. und 18. Jahrhundert. Archäologie und Museum 2, Beiträge zur Paläopathologie, 7-58.

Vlček, E. (1996): Syfilis v Čechách. Paleopatologické doklady výskytu v druhé polovině 2. tisíciletí. Vesmír, 2, 75-78.
Ward, P. J. (2016): Humerus. In: Bergman's Comprehensive Encyclopedia of Human Anatomic Variation (Tubbs, R. S.- Shoja, M. M.- Loukas, M., edd.), 63-67. Hoboken, New Jersey, USA.

Wojtucki, D. (2017): Rozhodnutí apelačního soudu týkající se kriminálních rozsudků soudu ve Slavkově u Brna v první polovině 18. stol. Anthropologia Integra, 8(2), 37-42.

Yekeler, E. - Tunaci, M. - Tunaci, A. - Dursun, M. - Acunas, G. (2006): Frequency of sternal variations and anomalies evaluated by MDCT. AJR, $186,956-960$. 